CZASOPISMO INŻYNIERII LĄDOWEJ, ŚRODOWISKA I ARCHITEKTURY JOURNAL OF CIVIL ENGINEERING, ENVIRONMENT AND ARCHITECTURE JCEEA, t. XXXIII, z. 63 (3/16), lipiec-wrzesień 2016, s. 263-270

Robert MARCINKOWSKI ${ }^{1}$

\title{
INTENSYWNA ZABUDOWA A OCHRONA WALORÓW KRAJOBRAZU
}

\begin{abstract}
Czy za pomocą ustaw da się wymusić dobrą architekturę? Zestawione w tytule dwa pojęcia postrzega się powszechnie jako stojące w opozycji. Ochrona krajobrazu polega bowiem głównie na ograniczeniach stawianych zabudowie, zaś zabudowa intensywna jest pojmowana jako zjawisko wobec niej (ochrony) przeciwstawne. Chciałbym poniżej omówić kilka aspektów architektury, które nie dają się łatwo (a może wcale) wymusić za pomocą formalno-prawnych ograniczeń. Zależy mi na nie traceniu z oka kwestii zasadniczej: jaki jest cel wprowadzania restrykcji? W jaki sposób mogą wpłynąć na jakość życia? Kwestię tę można też ująć następująco: jak mogłaby wyglądać architektura, gdyby jej barierą był (tylko) stan dostępnych technologii budowlanych? Postawienie sprawy w ten sposób nie daje doraźnych łatwych recept na dobre projektowanie. Jednak uważam je za celowe, gdyż skłania do szerszego widzenia problemu, w sposób łączący podejścia humanistyczne i techniczne. Mimo prowadzonej obecnie ochrony krajobrazu postępuje zanik punktów widokowych. Przynajmniej w tym przypadku jest ona nieskuteczna. Nie istnieje ochrona widoku z okna, mogącego jednak zniweczyć walory skądinąd dobrej architektury. Zabudowa o zwiększonej intensywności niekoniecznie jest dla krajobrazu złem, o ile może stanowić alternatywę dla zaśmiecania terenu wszechobecną zabudową rozproszoną.
\end{abstract}

Słowa kluczowe: intensywność zabudowy, uciążliwość sąsiedztwa, restrykcje prawne, ochrona krajobrazu, walory widokowe

\section{Wprowadzenie}

Czy za pomocą ustaw da się wymusić dobrą architekturę? Tempo i intensywność zmian w prawie budowlanym powodują, że wiara w celowość restrykcji wydaje się zwłaszcza u nas powszechna. Reakcją na niedostatki architektury jest mnożenie aktów prawnych i nowelizacji nakładających budynkom (i ich projektantom) nowe i nowe ograniczenia. Tymczasem stan realizacji wciąż ograniczeniom tym się wymyka. Chciałbym poniżej omówić kilka aspektów architektury, które nie dają się łatwo (a może wcale) ująć za pomocą formalnoprawnych ograniczeń. Stąd zestawienie $w$ tytule dwóch pojęć postrzeganych

\footnotetext{
${ }^{1}$ Robert Marcinkowski, Politechnika Krakowska, Instytut A-4, Zakład Budownictwa Ogólnego, ul. Warszawska 24; kontakt: 601489044, 126282459, rob500@gazeta.pl
} 
powszechnie jako stojące w opozycji. Ochrona krajobrazu polega bowiem głównie na ograniczeniach stawianych zabudowie, zaś zabudowę intensywną pojmuje się jako zjawisko wobec niej (ochrony) przeciwstawne.

\section{Uwagi metodologiczne}

W klasycznych podejściach zawartych w literaturze [1], [2], [7], [8]², jakość architektury analizuje się głównie jako jakość obiektów, określając także warunki jakim powinno odpowiadać ich usytuowanie [3]. Natomiast walory widokowe dotyczą często nie tyle budynków co przerw między nimi. Za podjęciem tematu przemawiają także poglądy na temat ochrony krajobrazu, spotykane zarówno na konferencjach naukowych jak i w środowisku projektujących architektów, w którym ochronę krajobrazu wiąże się z zakazami i eliminacją zabudowy. Za zasadniczą uważam natomiast kwestię: jaki jest cel tej ochrony, oraz wprowadzania ograniczeń? W jaki sposób mogą wpłynąć na jakość życia? Kwestię tę można też (na innej płaszczyźnie) ująć następująco: jak mogłaby wyglądać architektura, gdyby jej barierą był (tylko) stan dostępnych technologii budowlanych? Postawienie sprawy w ten sposób nie daje doraźnych łatwych recept na dobre projektowanie. Jednak (najbardziej w dydaktyce akademickiej) uważam je za celowe, gdyż skłania do szerszego widzenia problemu, w sposób łączący podejścia humanistyczne i techniczne.

\section{Ochrona krajobrazu a zagłada walorów widokowych}

Jeszcze niedawno położenie punktów widokowych w terenie było na tyle trwałe, że oznaczano je na mapach turystycznych (np. w znanych mi okolicach Krakowa [6]). Powstawanie nowych obiektów rzecz jasna ingeruje w sylwetę miasta (w Krakowie dominuje od dawna kontrast Wawelu z Elektrociepłownią Łęg widoczny z Kopca Kościuszki, rys. 1.), lecz znacznie gorsza jest systematyczna likwidacja miejsc, z których panoramy miasta można by jeszcze ogladać. Korony drzew zarastających okolice wymienionego Kopca to w sumie najmniejsze zło, choć i tu „ochrona zieleni” ukazuje swe absurdalne oblicze, likwidując walory widokowe pozornie chronionego terenu. Lecz wierzę, że zadrzewienie da się gabarytowo kontrolować przy odrobinie (chwilowo nieobecnego) rozsądku. Okolice Krakowa wymieniam jednak tylko jako egzemplifikację. Chodzi mi bowiem o postępujący bardzo szybko proces „urbanizacji”, czy też „dewelopin$\mathrm{gu}^{3}{ }^{3}$ jak eufemistycznie nazywa się marnowanie walorów terenu.

\footnotetext{
${ }^{2}$ Wybór jedynie przykładowy, obrazujący zróżnicowanie możliwych podejść do tematu.

3 „Dewelopingiem” nazywam skrótowo całość niefortunnych interakcji między zleceniodawcą, projektantem i urzędnikiem, których efekt w praktyce nie satysfakcjonuje żadnej ze stron [5].
} 


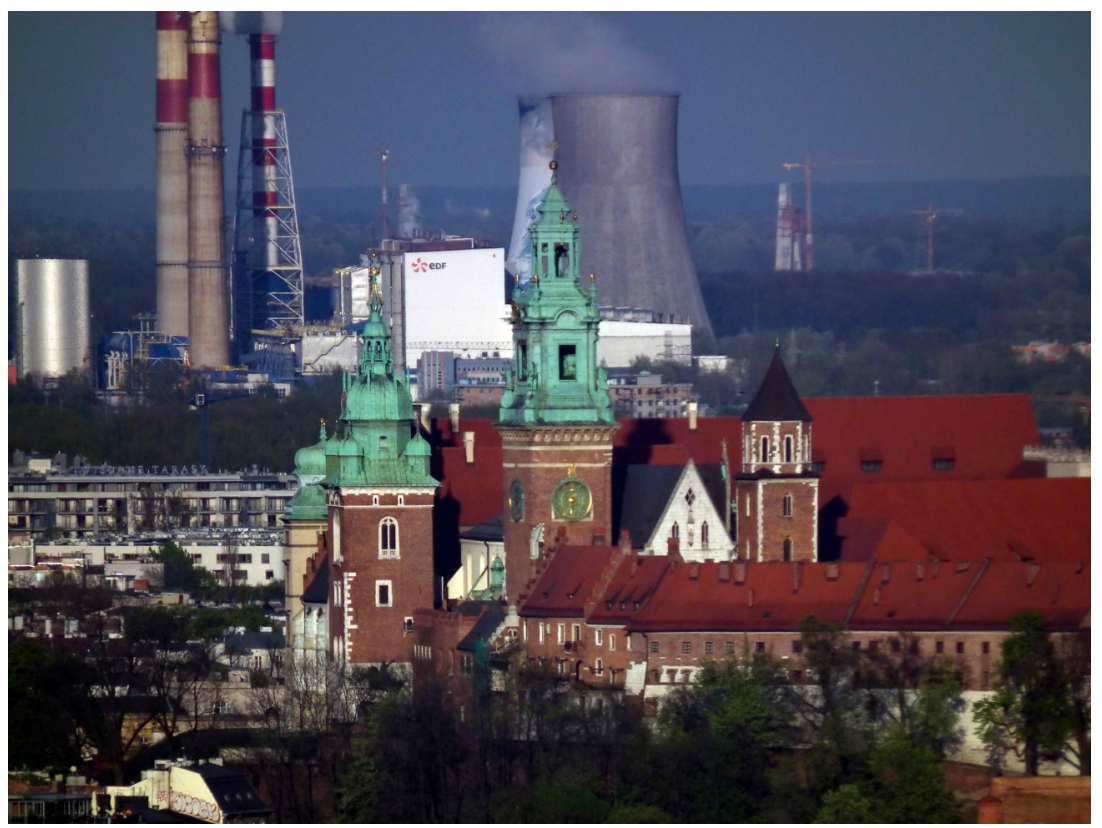

Rys 1 . Kontrasty w panoramie miasta są mniejszym złem, niż zanik miejsc z których miasto to można by jeszcze oglądać

Fig. 1. Contrasts in the panorama of the city is a lesser evil than the disappearance of places from which this city could still be seen

\section{Zabudowa rozproszona i uciążliwości sąsiedztwa}

Natomiast prawdziwą plagą wydają mi się formy zabudowy w których budynki przeszkadzają sobie wzajemnie, pokrywając zarazem cały uprzednio cenny widokowo teren ${ }^{4}$. „Było ładnie, ale ktoś się tu wybudował i nic nie dało się zrobić" - to może najczęstsza lecz i najmniej prawdziwa z możliwych konkluzji. Niezwykle podobne wypowiedzi usłyszeć można od urzędników a nawet samych architektów, co ilustruje sytuację jako patową, ze szkodą dla wszystkich stron. Gdyby jednak faktycznie „się nie dało” klincz taki musiałby panować (a nie panuje) na całym świecie.

Istnieją osiedla, czy też ich fragmenty, gdzie walory widokowe zostały zachowane (np. rys. 2). Chciałbym choćby najkrócej opisać nie poszczególne projekty, ale zasadnicze cechy takiego zespołu. Dzięki starannemu rozmieszczeniu budynków walory widokowe da się bowiem uzyskać nie tylko z okien czy tarasów, lecz i z ciągów komunikacyjnych osiedla.

- Widok ponad dachem sąsiada można uzyskać przy większych spadkach terenu i płaskich dachach budynków. Płaskie dachy kolidują jednak z dążeniem do

\footnotetext{
${ }^{4}$ Przykłady podkrakowskie to okolice Zelkowa, Wielkiej Wsi, czy Mogilan
} 
„regionalizacji” architektury. Trudny do zaakceptowania w warunkach polskich (przez ,przeciętnego" użytkownika) jest dom z parkingiem w poziomie dachu, lub generalnie na wyższej kondygnacji.

- Na terenach o małym spadku możliwe jest wykorzystanie widoku nie w poprzek a wzdłuż drogi, dzięki wyposażeniu budynków w wykusze i przeszklenia narożne. Warto odejść w tym wypadku od jednej dla wszystkich linii zabudowy, co znów natrafia na przeszkodę nie w sferze technologii, lecz bezwładności myślenia.

\section{Walory widokowe a wymogi ,regionalne”}

Użyty w cudzysłowie termin oznacza w skrócie komplet zapisów formalnoprawnych dążących do ochrony walorów lokalnej architektury i jej krajobrazowego otoczenia. Ochronę te realizuje się w praktyce poprzez ograniczenie powierzchni terenów przeznaczanych pod zabudowę, ustanowieniu limitów zabudowy za pomocą wskaźników, i wreszcie szczegółowo - przez ograniczenia w zakresie gabarytu i formy obiektów. Właśnie te ostatnie wymagają komentarza (nie tylko w kontekście zabudowy indywidualnej).

Cele ograniczeń stawianych budynkom określa się jako uporządkowanie przestrzenne zespołów mieszkaniowych oraz utrzymanie ciągłości kulturowej przez nawiązanie do regionalnej tradycji. I rzeczywiście następuje uporządkowanie, gdyż budynki zachwaszczające najbardziej wartościowe podmiejskie tereny są do siebie podobne. Pytanie jednak czy ciągłość kulturową regionu da się wymusić zakazami? Prawdziwie twórcze projekty wskazują, że nie.

I kolejne, bardziej istotne. Czy nie następuje wylanie dziecka z kąpielą? Czyli: czy restrykcje mają dodatnie przełożenie na jakość życia? Powierzchowna obserwacja osiedli może istotnie dostarczyć wrażenia pewnego „spokoju i ładu”, lecz zarazem wartościowy widokowo teren jako całość jest już niedostępny, ogrodzony i prywatny. Walory widokowe dostępne są więc dla marginalnej ilościowo grupy, głównie mieszkańców przed oknami których z jakichś powodów szczęśliwie nie „wybudował się" następny sąsiad.

Negatywny wpływ na jakość architektury w krajobrazie mają też inne zjawiska. Kontakt architekta z użytkownikiem zanikł (zastąpiony sprzedażą ,,projektów gotowych"), lub został zredukowany do nieistotnych korekt mieszkań (w inwestycjach deweloperskich).

Tzw. ,projekt gotowy” cechuje się zasadniczymi mankamentami:

- Projektant nigdy nie widział terenu na którym budynek ma być postawiony.

- Nie zna ludzi którzy mają w tym domu mieszkać, a więc ich potrzeb, których spełnienie stanowi o jakości zarówno projektu jak i życia przyszłych mieszkańców.

Ma jednak dla nabywcy zasadnicze zalety:

- Jest tani (w wersjach katalogowych rozdawany niekiedy za pół darmo), co sugeruje taniość inwestycji oraz, równie mylnie, nikłą wartość pracy projektantów. 
- Łatwiej uzyskać pozwolenie na budowę, gdyż projekt zaaprobowany na danym terenie zmniejsza utrudnienia typu biurokratycznego.

Sytuacja ta powoduje ,ujednolicenie" czyli po prostu zubożenie oferty (domów lecz także mieszkań) mimo pozornej różnorodności podaży.

\section{Jakość życia mierzona ,ucieczką z miast”}

Wspomniana powyżej jakość życia użytkownika jest jednym z najmniej istotnych elementów procesu inwestycyjnego. Jakość ta to pojęcie obrazowe, a jako zjawisko - niełatwo mierzalne. Chciałbym jednak spróbować je skonkretyzować, stawiając pytanie: jakie są przyczyny zjawiska „ucieczki z miast”? lub przekorniej: po co nam ten cały krajobraz? Dom rozumiany jako poprawne technicznie mieszkanie da się przecież zrealizować także w środowisku miejskim, czy wręcz „blokowisku”. Podobnie ma się rzecz z funkcjonalnością użytkową. W środowisku miejskim często brakuje nam natomiast:

- Kontaktu wzrokowego z krajobrazem, a najlepiej z choćby niewielkim fragmentem horyzontu. Co ważne, widok ten nie musi być (jak zazwyczaj odruchowo zakładamy) dookolny. Również horyzont nie musi być położony bardzo daleko. W gęstej tkance miejskiej wyobrażam sobie tę sytuację przestrzennie jako zespół zieleni parkowej widoczny z wielu usytuowanych wokół budynków.

- Choćby niewielkiej prywatnej przestrzeni ogrodowej niezagrożonej wglądem sąsiadów.

Dla wielu ludzi, gdyby mogli mieć to w bloku, ucieczka z miasta nie byłaby już potrzebna. Pogląd ten odnoszę zwłaszcza do starszego (mojego) pokolenia, statystycznie mniej widocznego w mediach społecznościowych ${ }^{5}$.

\section{Intensywność zabudowy bez uszczerbku dla zieleni}

Intensywność zabudowy nie jest sama w sobie żadnym dobrodziejstwem, co widać na terenach o zabudowie przegęszczonej, generującej dla mieszkańców / użytkowników narastającą uciążliwość wzajemnego sąsiedztwa. Dla naprawy tej sytuacji ustanawia się więc wskaźniki ograniczające gęstość i intensywność nowoprojektowanej zabudowy, oraz nakazujące pozostawienie wolnych od zabudowy powierzchni terenów zieleni miejskiej. Stopniowo w całym środowisku ${ }^{6}$ uciera się pogląd, że wskaźniki dla zabudowy i dla terenów zielonych stoją wobec siebie w opozycji, a dyskusje koncentrują się jedynie wokół kwestii jakie wskaźniki uznać za właściwe dla terenów podmiejskich, miejskich etc. Za zaletę i składową jakości życia milcząco uznaje się tym samym niską intensywność

\footnotetext{
${ }^{5}$ Poglądy te niełatwo ująć statystycznie. Czynią to jednak w pewnej mierze media społecznościowe, podsuwając w wyszukiwarkach poglądy nazwane tu (z oczywistym uproszczeniem) stereotypowymi [9], [10]

${ }^{6}$ Tu: zarówno projektantów, urzędników, jak i twórców prawa budowlanego
} 
zabudowy, a więc umieszczenie mieszkańców na możliwie rozległym terenie. Zarazem ubolewamy nad rozproszeniem zabudowy, niosącym innego rodzaju problemy, leżące zwłaszcza w sferze infrastruktury.

Tymczasem samo pojęcie ,powierzchni terenu” na naszych oczach staje się anachroniczne ${ }^{7}$. W centrach dużych miast (lecz nie tylko) teren niełatwo sensownie definiować, kiedy np. centra komunikacyjne i handlowe zrastają się w ciągłą strukturę. Zabudowa nie musi więc składać się z osobnych budynków, lecz raczej ze stref funkcjonalnych. $\mathrm{Z}$ technicznego punktu widzenia najistotniejsze podziały wynikają w istocie ze stref pożarowych, czy szerzej, z wymagań dotyczących bezpieczeństwa i możliwości ewakuacji.

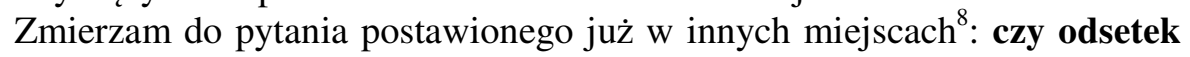
terenów zielonych mógłby przekroczyć sto procent? Jeśli budynki miałyby tylko stać obok siebie na powierzchni terenu jest to niemożliwe. Lecz powierzchnie zielone mogą przy obecnym stanie technologii biec pionowo, a także wkraczać do wnętrz.

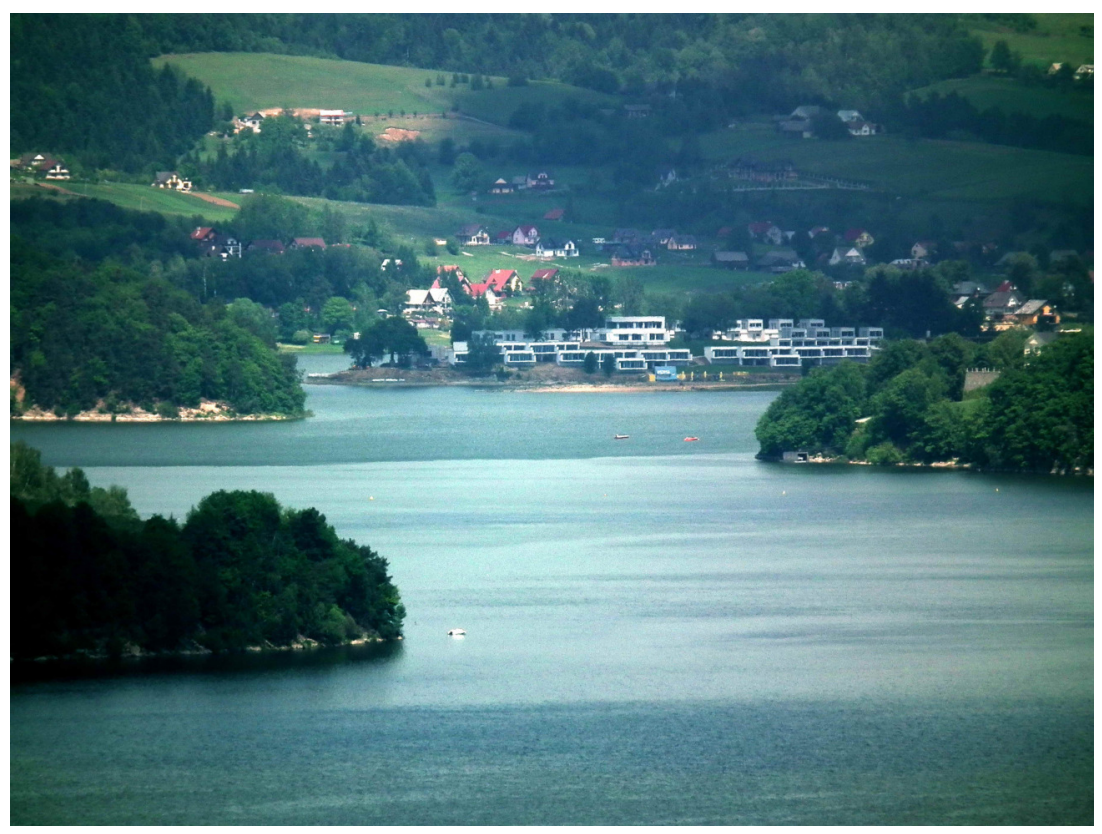

Rys. 2. Zwarta zabudowa w krajobrazie otwartym. Jezioro Rożnowskie i zespół zabudowy apartamentowej w Gródku nad Dunajcem

Fig. 2. The dense building in the open landscape. Roznow Lake and the complex of apartamental buildings. Gródek nad Dunajcem, Poland

\footnotetext{
${ }^{7}$ To „odkrycie” bynajmniej nie nowe. Nawet w moim skromnym dorobku pierwsza publikacja na ten temat liczy dwadzieścia lat [4]

${ }^{8}$ Jako wykład - na studiach podyplomowych WAPK. Pisemnie - w „Deweloping” jako czynnik degradacji miasta" [5]. W tamtej konferencji dominowały jednak wątki socjologiczne
} 
I druga kwestia wynikająca pośrednio z pierwszej: czy przy podobnie wysokim wskaźniku powierzchni zielonych nie jest do pomyślenia również stuprocentowa gęstość zabudowy?

Wreszcie kwestia najważniejsza, wiążąca powyższe rozważania ze sferą techniki. Otóż możliwy jest powszechny dostęp do domów / apartamentów o podobnych walorach przy istniejących już technologiach. Mam na myśli głównie takie oddzielenie od siebie sąsiadów, które zredukowałoby wzajemną uciążliwość. Zwarty zespół zabudowy przedstawiony przykładowo na rys. 2 zachowuje zarówno kontakt apartamentów $\mathrm{z}$ otwartym krajobrazem jak i prywatność tarasów. Zaznaczam, że poniższe uwagi nie odnoszą się jednak do wymienionego konkretnego obiektu, ale do zagadnień ogólniejszych:

- Zwrócenie wielu tarasów w tę samą stronę powoduje, że w wyglądzie budynku dominują formy ,prostopadłościenne”. Natomiast w postulowanym przeze mnie „bloku idealnym” widoczne elementy ścian i balustrad zostałyby przynajmniej częściowo przesłonięte przez miniaturowe ogrody umożliwiające mieszkańcom hodowlę roślin.

- Elewacja budynku mogłaby w percepcji przeciętnego obserwatora zniknąć. W istocie stanowiłyby ją jedynie powierzchnie przeszkleń skryte za (indywidualnie regulującą zacienienie) roślinnością. Technicznie a nawet ekonomicznie jest to całkowicie realne.

- Natomiast marzeniem mniej realnym jest „odchwaszczenie” sąsiednich połaci terenu, czy też podobne „ukrycie i zamaskowanie” rozproszonej na nim zabudowy.

\section{Podsumowanie}

- Mimo prowadzonej obecnie ochrony krajobrazu postępuje zanik punktów widokowych. Przynajmniej w tym przypadku ochrona jest nieskuteczna.

- Widok z okna to trudny do ochronienia czynnik, mogący jednak zniweczyć walory skądinąd dobrej architektury.

- Zabudowa o zwiększonej intensywności niekoniecznie musi być dla krajobrazu złem, o ile stanowi alternatywę dla zaśmiecania terenu (wszechobecną w Polsce) zabudową rozproszoną.

- Krajobraz można chronić przez różne formy działania, także nie wynikające wprost z wymogów prawa budowlanego.

- Oprócz alternatywy ,pozwolić-zabronić” istnieją inne możliwe podejścia (,,zamaskowac-zasłonić”) do form dysonansowych zarówno względem krajobrazu jak i urbanistycznego sąsiedztwa. 


\section{Literatura}

[1] Bogdanowski J., Kompozycja i planowanie w architekturze krajobrazu, Kraków 1976.

[2] Celadyn W., Architektura a systemy roślinne; studium relacji pomiędzy elementami architektonicznymi a roślinnymi, PK, Kraków 1992.

[3] Rozporządzenie Ministra Infrastruktury z dnia 6 listopada 2008 roku zmieniające rozporządzenie w sprawie warunków technicznych jakim powinny odpowiadać budynki I ich usytuowanie.

[4] Marcinkowski R., Dokąd zmierza architektura XXI stulecia, Kraków, miesięcznik Arkada nr 1/1996.

[5] Marcinkowski R., „Deweloping” jako czynnik degradacji miasta, [w:] Zmiany w przestrzeni współczesnych miast, Uniwersytet Rzeszowski 2016.

[6] Okolice Krakowa, mapa turystyczna, wydawnictwo Compass, Kraków 2006.

[7] Peters P., Rosner R., Małe zespoły mieszkaniowe, Arkady 1983.

[8] Seruga W., Zrównoważone środowisko mieszkaniowe w dydaktyce Katedry Kształtowania Środowiska Mieszkaniowego, Czasopismo Techniczne PK, 2007.

[9] http://wiadomosci.dziennik.pl/wydarzenia/artykuly/401093, mieszkancy-wsi-mlodsiniz-mieszkancy-miast-kobietya-wsiach-rodza-wiecej-dzieci-ludzie-rzadziejuciekaja-ze-wsi.html, wrzesień 2016.

[10] http://wiadomosci.onet.pl/kraj/rzeczpospolita-wielka-ucieczka-poza-miasto/md4mb, wrzesień 2016.

\section{HIGH DENSITY BUILDING VS PROTECTION OF LANDSCAPE}

\section{S u m m a r y}

Can using laws force a good architecture? The two terms compared in the title are widely seen as standing in opposition. Landscape protection means mainly the limitations of the building, and the intensive building is conceived as a phenomenon acting against it. I would like to discuss below some aspects of architecture, which are not easily (or at all) to force through formal and legal constraints. I care for keeping in mind the fundamental question: what is the purpose of introducing restrictions? How can it affect the quality of life? This issue can also be summarized as follows: architecture could look like if the barrier was (only) the state of the available building technologies? Putting the matter in this way does not give immediate easy recipes for good design. However, I consider it expedient, since it leads to a broader view of the problem, a mix of human and technical approach. In spite of the current landscape protection numerous viewpoints still do disappeare. At least in this case, the protection it ineffective. There is no protection of the view from the window, which could, however, wreck the values of the (otherwise good) architecture. Building of increased intensity it is not necessarily a danger for the landscape, as that may be an alternative to cluttering the area by omnipresent dispersed housing.

Keywords: building intensity, neighborhood inconvenience, law restrictions, protection of landscape, sightseeing values

DOI: $10.7862 /$ rb.2016.209

Przestano do redakcji: $30.09 .2016 r$.

Przyjęto do druku: 30.11.2016 r. 